\title{
STUDI EPIDEMIOLOGI PENYAKIT DEMAM BERDARAH DENGUE DI WILAYAH KERJA PUSKESMAS PURWOKERTO SELATAN KABUPATEN BANYUMAS TAHUN 2018
}

\author{
Erna Lusianah" ${ }^{1)}$, Budi Utomo ${ }^{2)}$ \\ Jurusan Kesehatan Lingkungan, Politeknik Kesehatan Kemenkes Semarang, \\ Jl.Raya Baturaden KM 12 Purwokerto, Indonesia
}

\begin{abstract}
Abstrak
[Studi Epidemiologi Penyakit Demam Berdarah Dengue Di Wilayah Kerja Puskesmas Purwokerto Selatan] Penyakit demam berdarah dengue (DBD) adalah penyakit menular yang disebkan oleh virus dengue dan ditularkan oleh nyamuk Aedes Aegypti. Berdasarkan laporan Dinas Kesehatan Kabupaten Banyumas, jumlah kasus Demam Berdarah Dengue di Kabupaten banyumas tahun 2015 dengan jumlah 264 kasus, tahun 2016 dengan jumlah 990, tahun 2017 dengan 68 kasus. wilayah Kecamtan Purwokerto selatan pada tahun 2015 sampai dengan 2017 dengan (IR=2,20). Tujuan Penelitian ini adalah mengetahui gambaran kejadian DBD yang berdasarkan variabel Epidemiologi (orang, waktu dan tempat) di Kecamatan Purwokerto Selatan Kabupaten Banyumas tahun 2015 sampai dengan 2017. Metode Penelitian yang digunakan adalah deskriptif. Pengumpulan data dilakukan dengan cara penelusuran data dan wawancara. Data disajikan dalm bentuk narasi struktur, grafik dan tabel. Analisis data dilakukan dengan cara analisis tabel dan grafik. Kesimpulan Penelitian adalah penderita umumnya antara 16 - 55 tahun dengan jenis kelamin perempuan dan dengan pekerjaan Pelajar. Waktu kejadian tertinggi kasus DBD ada di bulan Januari. Tempat persebaran tertinggi adalah kelurahan Teluk. Serta telah dilakukan pengendalian vektor DBD secara berkala dan berkelanjutan. Saranya adalah melakukan program PSN dan penyuluhan masyarakat 1 minggu 1 kali untuk menjaga kebersihan ligkungan dan melakukan kegiatan 3M plus untuk mencegah persebaran kasus DBD.
\end{abstract}

Kata kunci: Epidemiologi, Demam Berdarah Dengue

\begin{abstract}
[Epidemiological studies of dengue hemorrhagic fever (dbd) in the work area of puskesmas purwokerto south 2018]. Dengue hemorrhagic disease (DHF) is an infectious disease transmitted by dengue virus and transmitted by Aedes Aegypti mosquitoes. Based on the report of Banyumas District Health Office, the number of Dengue Hemorrhagic Fever cases in Banyumas District in 2015 amounted to 264 cases, 2016 with 990 number, 2017 with 68 cases. the southern Purwokerto Kecamtan region from 2015 to 2017 with $(I R=2.20)$. The purpose of this research is to know the description of DHF incidence based on Epidemiology variable (person, time and place) in South Purwokerto Sub-district of Banyumas Regency 2015 until 2017. The type of research used is descriptive. Data collection is done by data search and interview. Data is presented in the form of narrative structures, graphs and tables. Data analysis is done by analysis of tables and graphs. The conclusions of the study were general patients between 16 - 55 years old with female gender and with the work of the Student. The time of the highest incidence of dengue cases was in January. The highest dispersion area is the Teluk district. And has been done dengue vector control periodically and continuously. The trick is to conduct PSN program and community counseling 1 week 1 times to maintain clean environment and do $3 M$ plus activities to prevent the spread of DHF cases
\end{abstract}

Keywords: Epidemiology, Dengue Hemorhagic Fever (DHF),

\footnotetext{
${ }^{1)}$ E-mail: Astela505@gmail.com

${ }^{2)}$ E-mail: $\underline{\text { Budut17@yahoo.com }}$
} 


\section{Pendahuluan}

Penyakit Demam Berdarah Dengue (DBD) adalah penyakit menular yang disebabkan oleh virus dengue dan ditularkan oleh nyamuk Aedes aegypti (Depkes RI, 2003:4). DBD merupakan salah satu penyakit yang cenderung meningkat jumlah kasus dan penyebarannya serta sering menimbulkan Kejadian Luar Biasa dan kematian sehingga menjadi masalah kesehatan masyarakat (Depkes RI, 1992:1). Seluruh wilayah Indonesia, mempunyai risiko untuk kejangkitan penyakit DBD karena virus penyebab dan nyamuk penularnya tersebar luas, baik dirumah-rumah maupun ditempat umum, kecuali yang ketinggiannya lebih dari 1000m diatas permukaan laut (Depkes RI, 1992:6). Pada kasus-kasus terjangkitnya wabah DBD, awalnya hanya sering terjangkit di kota-kota besar terlebih pada kota-kota yang padat penghuninya, namun sejak beberapa tahun lalu, seiring dengan lajunya perkembangan pembangunan dan bertambah lancarnya transportasi, nyamuk Aedes aegypti telah pula ikut bertransmigrasi dan berkembang biak di hampir seluruh pelosok Indonesia (Indrawan, 2001:22)

Di Indonesia yang merupakan negara kepulauan dengan iklimnya yang tropik, terjadinya epidemik suatu penyakit di Jakarta yang kemungkinan besar adalah DBD dilaporkan pertama kali oleh David Baylon pada tahun 1779.Demam Berdarah Dengue adalah salah satu penyakit infeksi yang serius. Penyakit ini mulanya lebih sering menyerang anakanak dibanding orang dewasa, ataupun kaum remaja. Tetapi kini sudah merata, bisa menyerang siapa saja, tanpa batasan usia (Indrawan, 2001:21) Kasus DBD lebih cenderung meningkat selama musim penghujan. Perubahan musim agaknya mempengaruhi frekuensi gigitan nyamuk atau panjang umur nyamuk. Di Jakarta survei terhadap kebiasaan mengigit Aedes aegypti menunjukkan bahwa pada musim kemarau nyamuk itu paling sering mengigit pada pagi hari, sedangkan pada musim hujan puncak jumlah gigitan terjadi pada siang sampai sore hari (Sumarno Sunaryo, 1988:23).

Penyakit DBD merupakan penyakit infeksi yang masih menjadi masalah kesehatan masyarakat. Penyakit ini ditemukan nyaris diseluruh belahan dunia terutama di negara tropik dan subtropik baik secara endemik maupun epidemik dengan outbreak yang berkaitan dengan datangnya musim penghujan. Di Asia Tenggara termasuk Indonesia epidemik DBD merupakan problem abadi dan penyebab utama morbiditas dan mortalitas pada anak-anak. Kedepan peluang penyebaran DBD masih akan terus meningkat sehubungan dengan kendala pemberantasan vektor nyamuk dan mobilitas manusia semakin tinggi antar negara (Djono Djunaedi, 2006:8).

Dampak dari kerugian yang ditimbulkan akibat penyakit demam berdarah sangat besar. Ditinjau dari segi kesehatan, seseorang yang menderita penyakit demam berdarah mempunyai resiko yang tinggi. Mengingat penyakit ini belum ada obat dan vaksin dalam menyembuhkannya (Abdilillah Imron Nasution, 2015:2)

Faktor yang mempengaruhi kejadian penyakit demam berdarah dengue antara lain factor agent, hospes (host), dan lingkungan (environment). Faktor lingkungan fisik yaitu ( jenis tempat penampungan air, curah hujan, kecepatan angin, dan kepadatan nyamuk sebagai vektor penular penyakit.(Soegeng Soegijanto;2006,h.11).

Kabupaten Banyumas dalam dua tahun terahir jumlah kasus penderita DBD fluktuatif dengan data yang diperoleh dari dinas kesehatan kabupaten Banyumas sebagai berikut. Tahun 2015 sebanyak 264 kasus $(I R=16,43)$, terjadi pada tahun 2016 sebanyak 990 kasus $(I R=55,07)$ dan terjadi pada tahun 2017 sebanyak 68 kasus (IR=3,35). (Profil Dinkes Kabupaten Banyumas Tahun 2016 Kecamatan Purwokerto Selatan dengan jumlah penduduk 80.835 jiwa, merupakan wilayah yang endemis dan sering terjadi kasus DBD yaitu dengan distribusinya sebagai berikut: Karang Klesem 11 kasus ( $\mathrm{IR}=7,6)$, Berkoh 3 kasus (IR=2,73), Purwokerto Kidul 3 kasus (IR=4,09), Purwokerto kulon 7 kasus (IR=9,73), Tanjung 22 kasus (IR=20,88). Karang pucung 12 kasus (IR=8,97), Teluk 12 kasus $(\mathrm{IR}=7,20)$.

Berdasarkan latar belakang di atas penulis terdorong melakukan penelitian dengan judul "Studi Epidemiologi Penyakit Demam Berdarah Dengue Di Wilayah Kerja Puskesmas Purwokerto Selatan Kabupaten Banyumas Tahun 2018”.

\section{Bahan dan Metode}

Penelitian ini termasuk jenis penelitian deskriptif yang artinya menggambarkan kejadian Demam Berdarah Dengue Di Wilayah Kerja Puskesmas Purwokerto Selatan Kabupaten banyumas Tahun 2018.

Waktu dalam penelitian ini dibagi menjadi 3 tahap yang pertama tahap persiapan SeptemberDesember 2017, tahap pelaksanaan Januari-Maret 2018, dan tahap penyelesaian April-Mei 2018.

Cara Pengumpulan Data

a. Wawancara dilakukan untuk mendapatkan data dengan cara melakukan tanya jawab menggunakan kuesioner dengan pihak Puskesmas Purwokerto Selatan.

b. Observasi yaitu pengumpulan data dengan secara langsung.

Instrumen pengumpul data dalam penelitian ini, Kondisi Umum Lingkungan di Kecamatan Purwokerto Selatan dan Variabel Orang pada Penderita Penyakit Demam Berdarah Dengue.

Analisis yang digunakan dalam penelitian adalah deskriptif dengan menguraikan hasil pengamatan yang disajikan dalam bentuk tabel, grafik dan narasi. 


\section{Hasil dan Pembahasan}

\section{A. Gambaran Umum}

\section{Keadaan Geografi}

Wilayah Kecamatan Purwokerto Selatan terletak di Kabupaten Banyumas Wilayah Selatan Jl. Mr Moh yamin Kelurahan Karangklesem, Kecamatan Purwokerto Selatan Berada dalam Ketinggian 74 m dari Permukaan Air Laut , Suhu Lingkungan $21,4{ }^{\circ} \mathrm{C}-30,9{ }^{\circ} \mathrm{C}$ dan Luas wilayah adalah 1375,31 $\mathrm{Ha}$ atau $13,75 \mathrm{Km}^{2}$, terdiri dari 7 Kelurahan yaitu Kelurahan Tanjung $\left(1,59 \mathrm{Km}^{2}\right)$, Kelurahan Karangpucung $\quad\left(1,48 \quad \mathrm{Km}^{2}\right), \quad$ Kelurahan Karangklesem (3,02 $\left.\mathrm{Km}^{2}\right)$, Kelurahan Teluk $\left(3,51 \mathrm{Km}^{2}\right)$, Keluarahan Berkoh $\left(1,86 \mathrm{Km}^{2}\right)$, Kelurahan Purwokerto Kidul $\left(1,11 \mathrm{Km}^{2}\right)$, dan Kelurahan Purwokerto Kulon $\left(1,18 \mathrm{Km}^{2}\right.$

\section{Kondisi Demografi}

a. Jumlah Penduduk

Berdasarkan data dari Kecamatan Purwokerto Selatan jumlah penduduk sampai dengan akhir tahun 2017 adalah 76.510 jiwa dan jumlah penduduk laki-laki sebanyak 38.059 jiwa dan jumlah penduduk perempuan sebanyak 38.451 jiwa. Jumlah penduduk terbanyak yaitu Kelurahan Teluk (15.744 jiwa) dan yang paling sedikit Kelurahan Purwokerto Kidul (6.012 jiwa). Sementara itu, Kepadatan penduduk tertinggi justru berada di Kelurahan yaitu, yang dapat dilihat pada tabel dibawah ini

\begin{tabular}{llccc}
\hline No & Kelurahan & \multicolumn{3}{c}{$\begin{array}{c}\text { Jumlah } \\
\text { Penduduk }\end{array}$} \\
\hline & & 2015 & 2016 & 2017 \\
\cline { 3 - 5 } 1. & Tanjung & 9.607 & 10.535 & 10.583 \\
2. & Karang Pucung & 11.428 & 13.364 & 11.669 \\
3. & Karangklesem & 12.967 & 14.373 & 15.480 \\
4. & Teluk & 16.943 & 17.093 & 15.744 \\
5. & Berkoh & 10.913 & 10.959 & 10.467 \\
6. & Purwokerto & 7.418 & 7.322 & 6.012 \\
& Kidul & & & \\
7. & Purwokerto & 7.274 & 7.189 & 6.555 \\
& Kulon & & & \\
\hline & Jumlah & $\mathbf{7 6 . 5 5 9}$ & $\mathbf{8 0 . 8 3 5}$ & $\mathbf{7 6 . 1 5 0}$
\end{tabular}

b. Jumlah Penduduk Menurut Jenis Kelamin

Data jumlah penduduk menurut jenis kelamin di wilayah Kecamatan Purwokerto Selatan, dapat dilihat pada tabel di bawah ini.

\begin{tabular}{llllll}
\hline No & Kelurahan & $\begin{array}{c}\text { Laki- } \\
\text { Laki }\end{array}$ & \multicolumn{3}{c}{ Perempuan } \\
\cline { 3 - 6 } & Jiwa & \% & Jiwa & \% \\
\hline $\mathbf{1 .}$ & Tanjung & 5.220 & 13,7 & 5.363 & 13,9 \\
\hline $\mathbf{2 .}$ & $\begin{array}{l}\text { Karang } \\
\text { Pucung }\end{array}$ & 5.901 & 15,5 & 5.768 & 15,0 \\
\hline $\mathbf{3 .}$ & Karangklesem & 7.689 & 20,2 & 7.791 & 20,2 \\
\hline $\mathbf{4 .}$ & Teluk & 7.952 & 20,8 & 7.792 & 20,2 \\
\hline $\mathbf{5 .}$ & Berkoh & 5.155 & 13,5 & 5.312 & 13,8 \\
\hline $\mathbf{6 .}$ & Purwokerto & 2.962 & 7,7 & 3.086 & 8,0 \\
\hline Kidul & Purwokerto & 3.216 & 8,4 & 3.339 & 8,6 \\
\hline & Kulon & & & & \\
\hline & Jumlah & 38059 & 100 & 38451 & 100 \\
\hline & & & & & \\
\hline
\end{tabular}

B. Data Khusus

1. Variabel Orang

\section{a. Data Umur}

\begin{tabular}{llcccccc}
\hline No & $\begin{array}{l}\text { Gol. } \\
\text { Umur }\end{array}$ & \multicolumn{7}{c}{ Tahun } \\
\cline { 2 - 8 } 1 & $\begin{array}{l}\mathbf{2 0 1 5} \\
0-<1\end{array}$ & 1 & 1,1 & 1 & 1,4 & 0 & 0 \\
th & $\begin{array}{l}\text { 1-5 } \\
\text { th }\end{array}$ & 4 & 4,5 & 6 & 8,6 & 5 & 55,5 \\
3 & $\begin{array}{l}\text { 6-15 } \\
\text { th }\end{array}$ & 21 & 23,3 & 22 & 31,4 & 4 & 44,5 \\
4 & $\begin{array}{l}16-55 \\
\text { th }\end{array}$ & 57 & 63,3 & 41 & 58,6 & 0 & 0 \\
5 & $\begin{array}{l}>56 \\
\text { th }\end{array}$ & 7 & 7,8 & 0 & 0 & 0 & 0 \\
\hline Jumlah & $\mathbf{9 0}$ & $\mathbf{1 0 0}$ & $\mathbf{7 0}$ & $\mathbf{1 0 0}$ & $\mathbf{9}$ & $\mathbf{1 0 0}$ \\
\hline
\end{tabular}

Berdasarkan data diatas maka dapat diketahui bahwa banyaknya penderita Demam Berdarah Dengue pada tahun 2015 tertinggi golongan umur 16-55 tahun dengan 57 kasus $(63,3 \%)$. Dan terendah golongan umur $0>1$ tahun 1 kasus $(1,1 \%)$. Tahun 2016 tertinggi golongan umur 16-55 tahun dengan 41 kasus $(58,6 \%)$. Dan terendah golongan umur $0>1$ tahun 1 kasus (1,4\%). Dan tahun 2017 golongan umur 1-5 tahun dengan 5 kasus $(55,5 \%)$ dan golongan umur 6-15 tahun 4 kasus $(44,5 \%)$ dari tahun 2015 sampai dengan 2017 total 169 kasus.

Pada usia 6-15 tahun dan 16-55 tahun sangat dimungkinkan terkena penyakit DBD karena tergolong usia produktif. Pada golongan umur 6-15 tahun dan 16-55 tahun kebanyakan penduduk melakukan aktivitas pada siang hari diluar rumah pada suatu tempat dengan jumlah orang banyak dan jika terdapat orang yang sudah terkena Demam Berdarah dengue maka dapat mudah tertular, dan nyamuk Aedes aegypti melakukan aktifitas menggigit mulai pagi sampai petang dengan 2 puncak aktifitas antara pukul 09.00-10.00 dan 16.00-17.00. Penderita Demam Berdarah Dengue di Banyumas tahun 2017 didominasi umur $>15$ tahun dengan 62 kasus. Selaras dengan penelitian (Nur Zahra Priharyanti, 2017) di Purbalingga menyebutkan bahwa 
karateristik responden pada tahun 2014 berdasarkan umur paling banyak pada kelompok umur 12-25 tahun, 53 kasus $(38,97 \%)$

\section{b. Jenis Kelamin}

\begin{tabular}{llllllll}
\hline $\mathbf{N}$ & Jenis & \multicolumn{6}{c}{ Tahun } \\
o & Kelamin & & \multicolumn{5}{c}{} \\
\hline & & $\mathbf{2 0 1}$ & $\mathbf{\%}$ & $\mathbf{2 0 1}$ & $\mathbf{\%}$ & $\mathbf{2 0 1}$ & $\mathbf{\%}$ \\
& & $\mathbf{5}$ & & $\mathbf{6}$ & & $\mathbf{7}$ & \\
\cline { 3 - 8 } 1. & Laki- & 29 & 32, & 31 & 44, & 3 & 33, \\
& Laki & & 3 & & 3 & & 3 \\
2 & Perempua & 61 & 67, & 39 & 55, & 6 & 66, \\
& n & & 7 & & 7 & & 7 \\
\hline & Jumlah & $\mathbf{9 0}$ & $\mathbf{1 0 0}$ & $\mathbf{7 0}$ & $\mathbf{1 0 0}$ & $\mathbf{9}$ & $\mathbf{1 0 0}$ \\
\hline
\end{tabular}

Hasil Penelitian Berdasarkan Jenis Kelamin pada tahun 2015 sampai dengan tahun 2017 penderita DBD terbanyak berjenis kelamin perempuan. Pada tahun 2015 terdapat 29 kasus $(32,3 \%)$ laki-laki dan 61 kasus $(67,7 \%)$ perempuan, pada tahun 2016 terdapat 31 kasus (44,3\%) laki-laki dan 39 kasus $(55,7 \%)$ perempuan, pada tahun 2017 terdapat 3 kasus $(33,3 \%)$ laki-laki dan 6 kasus $(66,7 \%)$ perempuan.

Hal tersebut dapat disebabkan karena jumlah penduduk jenis kelamin perempuan lebih banyak di banding laki-laki dan sangat dimungkinkan tergigit nyamuk Aedes aegypti. Penderita Demam Berdarah Dengue di Banyumas tahun 2016 didominasi Jenis Kelamin Perempuan. Jenis Kelamin Perempuan 520 kasus $(I R=51,9)$ dan Laki-laki 470 kasus (IR=46,1). Selaras dengan penelitian (Nur Zahra Priharyanti, 2017) di Purbalingga menyebutkan bahwa karateristik responden pada tahun 2015 berdasarkan Jenis Kelamin paling banyak Jenis Kelamin Laki-laki 98 kasus (IR=35,8).

\section{c. Pekerjaan}

\begin{tabular}{|c|c|c|c|c|c|c|c|}
\hline \multirow{2}{*}{$\begin{array}{r}\mathbf{N} \\
\mathbf{0}\end{array}$} & \multirow{2}{*}{$\begin{array}{l}\text { Pekerja } \\
\text { an }\end{array}$} & \multicolumn{6}{|c|}{ Tahun } \\
\hline & & $\begin{array}{l}201 \\
5\end{array}$ & $\%$ & $\begin{array}{l}201 \\
6\end{array}$ & $\%$ & $\begin{array}{l}201 \\
7\end{array}$ & $\%$ \\
\hline 1 & Balita & 5 & 5,6 & 7 & 10 & 5 & $\begin{array}{c}55, \\
5\end{array}$ \\
\hline 2 & Pelajar & 30 & $\begin{array}{l}33, \\
3\end{array}$ & 38 & $\begin{array}{c}54, \\
2\end{array}$ & 4 & $\begin{array}{c}44, \\
5\end{array}$ \\
\hline 3 & IRT & 24 & $\begin{array}{l}26, \\
7\end{array}$ & 8 & $\begin{array}{c}11 \\
4\end{array}$ & 0 & 0 \\
\hline 4 & Petani & 12 & $\begin{array}{l}13, \\
3\end{array}$ & 6 & 8,8 & 0 & 0 \\
\hline 5 & $\begin{array}{l}\text { Pedagan } \\
\mathrm{g}\end{array}$ & 7 & 7,8 & 2 & 2,8 & 0 & 0 \\
\hline 6 & PNS & 3 & 3,3 & 3 & 4,2 & 0 & 0 \\
\hline 7 & Swasta & 9 & 10 & 6 & 8,8 & 0 & 0 \\
\hline & Jumlah & 90 & 100 & 70 & 100 & 9 & 100 \\
\hline
\end{tabular}

Hasil Penelitian Berdasarkan Pekerjaan pada tahun 2015 penderita DBD terbanyak Pelajar dengan 30 kasus $(33,3 \%)$, IRT 24 kasus $(26,7 \%$ dan terendah PNS dengan 3 kasus $(3,3 \%)$. Pada tahun 2016 penderita tebanyak terjadi pada Pelajar dengan 38 kasus $(54,2 \%)$, IRT 8 kasus $(11,4)$, dan terendah Pedagang dengan 2 kasus $(2,8 \%)$,Dan pada tahun 2017 penderita DBD terbanyak Balita dengan 5 kasus $(55,5 \%)$ dan terendah pada pelajar 4 kasus $(44,5 \%)$.

Berdasarkan hasil penelitian penyakit Demam Berdarah Dengue menurut Pekerjaan tertinggi pada tahun 2015 sampai dengan 2017 terjadi pada Pelajar dengan jumlah 73 kasus dan terendah terjadi pada PNS 6 kasus. Hal ini dapat disebabkan karena Pelajar masih dalam usia produktif dan banyak melakukan aktivitas diluar ruangan dan berhubungan dengan banyak orang sehingga dapat memungkinkan tertular pada saat di sekolah, maupun saat bermain di luar ruangan.

\section{Variabel Epidemiologi Berdasarkan Waktu}

\section{Kasus Berdasarkan Waktu 2015-2017}

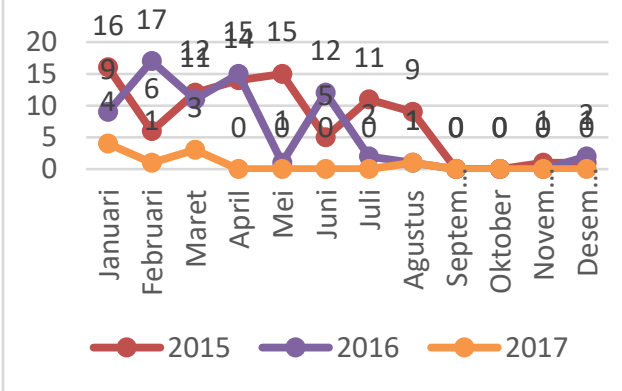

Hasil Penelitian Berdasarkan Waktu pada tahun 2015 sampai dengan tahun 2017 kejadian tertinggi terjadi pada bulan Januari sampai dengan bulan Agustus secara terus menerus pada 3 tahun terahir dengan jumlah kasus pada bulan Januari 29 kasus, Feruari 24 kasus, Maret 26 kasus, April 29 kasus, Mei 16 kasus, Juni 17 kasus, Juli 13 kasus, dan Agustus 10 kasus. Sedangkan bulan September sampai dengan bulan desember mengalami penurunan kasus dengan jumlah 3 kasus dengan total selama tahun 2015 sampai dengan 2017169 penderita Demam Berdarah Dengue.

Hal ini disebabkan karena bulan Januari sampai dengan bulan Agustus masih termasuk musim hujan sehingga banyak genangan air diluar rumah dan memungkinkan sekali nyamuk aedes aegypti. berkembang biak di tempat-tempat yang tergenang air (Pot bunga, Selokan, 
Tempayan, Kaleng Bekas dll). Kegiatan untuk mengurangi penyebaran penyakit demam berdarah dengue dapat dilakukan dengan upaya pengendalian seperti kegiatan pemberantasan sarang nyamuk (PSN) dan masyarakat dapat berperan aktif dalam pelaksanaannya. Di Wilayah kerja Puskesmas Purwokerto Selatan, kesadaran masyarakat akan PSN yang masih kurang sehingga pada tahun 2017 masih terdapat 9 kasus meskipun jumlahnya menurun. Selaras dengan penelitian (Nur Zahra Priharyanti, 2017) di Purbalingga menyebutkan bahwa karateristik responden pada tahun 2014 berdasarkan waktu paling banyak dan tertinggi pada bulan Februari dengan 70 kasus.

\section{Variabel Epidemiologi Berdasarkan Tempat}

\begin{tabular}{|c|c|c|c|c|c|c|c|}
\hline \multirow[b]{2}{*}{ No } & \multirow[b]{2}{*}{ Kelurahan } & \multicolumn{3}{|c|}{ Tahun } & \multicolumn{3}{|c|}{ Insiden Rate (IR) } \\
\hline & & 2015 & 2016 & 2017 & 2015 & 2016 & 2017 \\
\hline 1. & Tanjung & 6 & 22 & 0 & 1,66 & 2,08 & 000 \\
\hline 2. & $\begin{array}{l}\text { Karang } \\
\text { Pucung }\end{array}$ & 18 & 12 & 2 & 1,57 & 0,89 & 0,17 \\
\hline 3. & Karangklesem & 21 & 11 & 1 & 1,61 & 0,76 & 0,06 \\
\hline 4. & Teluk & 20 & 12 & 2 & 1,18 & 0,70 & 0,12 \\
\hline 5. & Berkoh & 12 & 3 & 0 & 1,09 & 0,28 & 000 \\
\hline 6. & $\begin{array}{l}\text { Purwokerto } \\
\text { Kidul }\end{array}$ & 10 & 3 & 4 & 1,34 & 0,40 & 0,66 \\
\hline 7. & $\begin{array}{l}\text { Purwokerto } \\
\text { Kulon }\end{array}$ & 3 & 7 & 0 & 0,41 & 0,97 & 000 \\
\hline & Jumlah & 90 & 70 & 9 & 8,86 & $\mathbf{6 , 0 8}$ & 1,01 \\
\hline
\end{tabular}

Hasil Penelitian Berdasarkan Tempat pada tahun 2015-2017 terdapat total 169 penderita. Pada tahun 2015 terdapat 90 kasus. Dengan kasus terbanyak pada Kelurahan Karangklesem dengan 21 kasus $(\mathrm{IR}=1,61)$ dan terendah pada Kelurahan Purwokerto Kulon dengan 3 kasus ( $\mathrm{IR}=1,34)$ sedangkan kelurahan Tanjung 6 kasus $(\mathrm{IR}=1,66)$, Kelurahan Karang Pucung 18 kasus (IR=1,57), kelurahan Teluk 20 kasus (IR=1,18), Kelurahan Berkoh 12 kasus $(\mathrm{IR}=1,09)$, Kelurahan Purwokerto Kidul 10 kasus (IR=0,41).

Pada tahun 2016 terdapat 70 kasus, dengan kasus terbanyak pada Kelurahan Tanjung 22 kasus (IR=2,08) dan Kelurahan terendah kelurahan Purwokerto Kidul 3 kasus (IR=0,40), Kelurahan Berkoh 3 kasus (IR=0,28), sedangkan kelurahan Karang Pucung 12 kasus (IR=0,89), Kelurahan Karangklesem 11 kasus $\quad(\mathrm{IR}=0,76)$, Kelurahan Teluk 12 kasus (IR=0,70), Kelurahan Purwokerto Kulon 7 kasus (IR=0,97). Pada tahun 2017 terdapat 9 kasus, Kelurahan tertinggi Purwokerto Kidul 4 kasus $(\mathrm{IR}=0,66)$, Kelurahan Karang pucung 2 kasus (IR=0,17) dan kelurahan Teluk 2 kasus $(\mathrm{IR}=0,12)$ sedangkan terendah kelurahan Karangklesem 1 kasus (IR=0,06). Berdasarkan hasil penelitian penyakit Demam Berdarah Dengue menurut Tempat tertinggi pada tahun 2015 sampai dengan 2017 terjadi pada Kelurahan Teluk dengan jumlah 34 kasus dan terendah terjadi pada Kelurahan Purwokerto Kulon dengan 10 kasus. Hal ini disebabkan karena Kelurahan Teluk terletak pada perkotaan dan kurangnya kesadaran penduduk akan kebersihan lingkungan dan kesehatan bagi tubuh. Selaras dengan penelitian (Nur Zahra Priharyanti, 2017) di Purbalingga menyebutkan bahwa karateristik responden pada tahun 2014 berdasarkan Tempat paling banyak dan tertinggi pada Kelurahan Wirasna dengan 45 kasus.

\section{Program Pengendalian Demam Berdarah Dengue Di Wilayah Kerja Puskesmas Purwokerto Selatan.}

\begin{tabular}{|c|c|c|c|c|}
\hline \multirow[t]{2}{*}{ No } & \multirow[t]{2}{*}{ Kelurahan } & \multicolumn{3}{|c|}{$\begin{array}{c}\text { Pengendalian Yang } \\
\text { Dilakukan }\end{array}$} \\
\hline & & $\overline{\mathbf{P S N}}$ & Fogging & $\begin{array}{l}\text { Penyuluh } \\
\text { an }\end{array}$ \\
\hline 1 & Tanjung & $\checkmark$ & $\checkmark$ & $\checkmark$ \\
\hline 2 & Karang Pucung & $\checkmark$ & $\checkmark$ & $\checkmark$ \\
\hline 3 & Karangklesem & $\checkmark$ & $\checkmark$ & $\checkmark$ \\
\hline 4 & Teluk & $\checkmark$ & $\checkmark$ & $\checkmark$ \\
\hline 5 & Berkoh & $\checkmark$ & $\checkmark$ & $\checkmark$ \\
\hline 6 & $\begin{array}{l}\text { Purwokerto } \\
\text { Kidul }\end{array}$ & $\checkmark$ & $\checkmark$ & $\checkmark$ \\
\hline 7 & $\begin{array}{l}\text { Purwokerto } \\
\text { Kulon }\end{array}$ & $\checkmark$ & $\checkmark$ & $\checkmark$ \\
\hline
\end{tabular}

Hasil Penelitian Pengendalian Puskesmas Purwokerto Selatan telah melakukan hampir semua pengendalian. Ada beberapa pengendalian yang telah dilakukan oleh Puskesmas Purwokerto Selatan seluruh kelurahan seperti Pemberantasan Sarang Nyamuk (PSN), Fogging dan Penyuluhan tentang penyakit demam berdarah dengue. Pada pelaksanannya Puskesmas Purwokerto Selatan melaksanakan PSN, Kelurahan Tanjung periode waktu 1 minggu sekali, Kelurahan Karang Pucung 2 period waktu 2 minggu sekali, Kelurahan Teluk periode waktu 1 bulan sekali, Kelurahan Berkoh 1 Bulan sekali, kelurahan Purwokerto Kidul 1 bulan sekali, Kelurahan Purwokerto Kulon 2 minggu sekali, Karangklesem 1 bulan sekali. oleh petugas puskesmas dengan jumlah 2 orang petugas dan dibantu kader tiap kelurahan. Penyuluhan dilakukan menggunakan metode audio visual yaitu 
menggunakan LCD dan bahan presentasi. Penyuluhan mengenai pemberantasan sarang nyamuk (PSN), dan bahaya penyakit demam berdarah dengue. Penyuluhan dilakukan di semua wilayah kerja Puskesmas Purwokerto Selatan.

Puskesmas Purwokerto Selatan memiliki waktu yang berbeda dalam pelaksaan penyuluhan. Pada Puskesmas Purwokerto Selatan, penyuluhan dilakukan dengan periode 1 bulan sekali pada setiap kelurahan. Penyuluhan dilakukan bersama dengan petugas dari Kelurahan/Desa setempat. Adapun periode lanjutan yaitu 3 kali dalam satu tahun. Petugas yang melaksanakan kegiatan penyuluhan dari puskesmas Purwokerto Selatan adalah 2 atau 3 orang. Selaras dengan penelitian (Nur Zahra Priharyanti, 2017) di Purbalingga menyebutkan bahwa Kecamatan Purbalingga Telah melakukan hampir semua pengendalian, satu pengendalian yang belum dilakukan yaitu survey nyamuk dewasa. Ada beberapa pengendalian yang telah dilakukan oleh seluruh kelurahan seperti Pemeriksaan Jentik Berkala (PJB), Pemberantasan Sarang Nyamuk (PSN), dan Penyuluhan demam berdarah dengue.

\section{Kesimpulan}

1. Penyebaran penyakit demam berdarah dengue (DBD) di Kecamatan Purwokerto Selatan berdasarkan variabel golongan umur tertinggi sejak tahun 2015-2017 adalah golongan umur pelajar yaitu 16-22 tahun dan 6-15 tahun. Penyebaran penyakit DBD berdasarkan variabel jenis kelamin tertinggi sejak tahun 2015-2017 adalah Perempuan. Penyebaran penyakit DBD berdasarkan variable pekerjaan tertinggi terjadi pada Pelajar.

2. Kasus demam berdarah dengue (DBD) yang terjadi di Kecamatan Purwokerto Selatan berdasarkan variabel waktu tertinggi sejak tahun 2015-2017 adalah pada bulan Januari sampai dengan bulan agustus secara terus menerus pada 3 tahun terahir denan jumlah kasus bulan Januari 29 kasus, Februari 24 kasus, maret 26 kasus, April 29 kasus, Mei 16 kasus, Juni 17 kasus, Juli 13 kasus.

3. Kasus demam berdarah dengue (DBD) yang terjadi di Kecamatan Purwokerto Selatan berdasar tempat tertinggi pada tahun 2015-2017 adalah di Kelurahan Teluk dengan jumlah 34 kasus.

4. Di Kecamatan Purwokerto Selatan yaitu wilayah kerja Puskesmas Purwokerto Selatan telah melakukan beberapa pengendalian Demam Berdarah Dengue (DBD) seperti Kegiatan Pemberantasan Sarang Nyamuk (PSN), kegiatan fogging, dan penyuluhan. kegiatan Pemberantasan Sarang Nyamuk (PSN) dilaukan oleh seluruh masyarakat Kecamatan Purwokerto Selatan sesuai program yang berlaku di Puskesmas Purwokerto. Kegiatan fogging dilaksanakan setelah terjadinya kenaikan kasus atau telah terjadi kasus di satu wilayah lebih dari $2(>2)$ dan/atau telah terjadi kematian akibat kasus demam berdarah dengue. Sedangkan kegiatan penyuluhan dilakukan diseluruh wilayah Kecamatan Purwokerto Selatan oleh petugas Puskesmas pada saat melakaukan fogging dan pertemuan kader.

\section{Ucapan Terimakasih}

Terima kasih disampaikan kepada Wilayah Kerja Puskesmas Purwokerto Selatan, Jurusan Kesehatan Lingkungan, dosen pembimbing karya tulis ilmiah Politeknik Kesehatan Kemenkes Semarang serta pihak-pihak yang terkait sehingga penelitian ini dapat terlaksanakan.

\section{Daftar Pustaka}

Chasan S, Kusnadi. 2006. Pengendalian Vektor dan Binatang Pengganggu(Vektor Control Manual). Makasar: Poltekkes Kesehatan Lingkungan Makasar.

Departemen Kesehatan R.I. Direktorat Jendral Pengendalian Penyakit Dan Penyehatan Lingkungan (DIT.JEN.PP\&PL), 2001, Pedoman Ekologi Dan Aspek Perilaku Vektor, Jakarta : DIT.JEN.PP\&PL.

Departemen Kesehatan R.I. Direktorat Jendral PPM \& PLP, 1986, Demam Berdarah Dengue Epidemiologi dan Pemberantasan Di Indonesia, Jakarta DIT.JEN.PPM\&PLP.

Dinas Kesehatan Kabupaten Banyumas, 2015, Laporan Kasus Demam Berdarah Dengue Tahun 2015, Banyumas :

Dinas Kesehatan Kabupaten Banyumas, 2016, Laporan Kasus Demam Berdarah Dengue Tahun 2016, Banyumas :

Dinas Kesehatan Kabupaten Banyumas, 2017, Laporan Kasus Demam Berdarah Dengue Tahun 2017, Banyumas :

Depkes RI, 1992, Petunjuk Teknis Penemuan Pertolongan dan Pelaporan Penderita Penyakit DBD, Jakarta: Ditjen PPM dan PPL. 
Kementerian Kesehatan RI Ditjen PP\&PL Dit. PPBB. 2012. Petunjuk Teknis Pemberantasan Sarang Nyamuk oleh Jumantik. Jakarta : DIT.JEN.PP\&PL.

Lawrence F Wolper, 2001, Administrasi Layanan Kesehatan, Jakarta: EGC.

Pramurditya Ratna. 2014.Deskripsi Pelaksanaan Pemberantasan SArang Nyamuk (PSN) Demam Berdarah Dengue (DBD) Di Kelurahan Karangpucung Kecamatan Purwokerto Selatan Kabupaten Banyumas Tahun 2014 . Purwokerto : Jurusan Kesehatan Lingkungan Poltekkes Kemenkes Semarang.

Nur Nasry Noor, 2008, Epidemiologi, Jakarta: Rineka Cipta.
Nur Zahra Priharyati. 2017.Deskripsi Epidemiologi dan Pengendalian vektor Demam Berdarah Dengue di Kecamatan Purbalingga Kabupaten Purbalingga Tahun 2012-2016

Soegeng Soegijanto, 2006, Demam Berdarah Dengue, Surabaya: Airlangga University Press.

Sumarmo Sunaryo, 1988, Demam Berdarah Dengue pada Anak, Jakarta: Universitas Indonesia.

Utari, P. 2012. Deskriptif Demam Berdarah Dengue Berdasarkan Variabel Epidemiologi di Wilayah Puskesmas I Wangon Kabupaten Banyumas Tahun 2011. Purwokerto : Jurusan Kesehatan Lingkungan Poltekkes Kemenkes Semarang. 